\title{
Your Financial Action PLAN ${ }^{1}$
}

\author{
ADAPTED BY JOSEPHINE TURNER AND MICHAEL GUTTER ${ }^{2}$
}

\section{OVERVIEW}

Families today are faced with a financial puzzle. In addition to stretching their income from one paycheck to the next, they face the necessary task of planning for future financial needs. It is easy to get caught up in everyday living, and forget to look ahead. A secure financial future requires setting goals and carefully managing your money so goals can be met.

This lesson is designed to help you and your family create a financial action plan that will enable you to make wise decisions now about your future financial success. When you have completed this lesson, you will have:

- Assessed your family's values

- Learned how to set and reach specific spending goals

- Identified your income and spending patterns with an eye towards developing a budget

The lesson ends with a brief introduction to developing a savings plan, which is discussed later in this series. After completing this lesson and the accompanying worksheets, you should be well on your way to understanding your spending patterns, so that you can take control of them and your future.

\section{WHAT'S IMPORTANT TO YOU?}

Before you can make your financial dreams come true, you need to think about what things are important to you and your family. The values you identify will help you to determine the direction you take with your finances. The following list identifies some things that are important to families. Pick out the things that are most important to you and your family and place a " 1 " beside them. Place a " 2 " by the things that are sort of important. Place a " 3 " beside the things that aren't very important.

$$
\begin{aligned}
& \text { religion } \\
& \text { education } \\
& \text { food/recreation }
\end{aligned}
$$

health

culture (theater, movies, dance recitals)

household furnishings

1. This document is FCS5204, one in a series of the Department of Family, Youth and Community Sciences, Florida Cooperative Extension Service, Institute of Food and Agricultural Sciences, University of Florida, Gainesville, FL 32611. This material was adapted for use in Florida with permission of the University of Idaho Cooperative Extension System. Originally published July 2001 as Show Me the Money, Lesson 1. Revised March 2009, and October 2009. Please visit the EDIS Web site at http://edis.ifas.ufl.edu.

2. Josephine Turner, Ph.D., CFP, professor, Family and Consumer Economics and Michael Gutter, Ph.D., professor, Family and Financial Management, Department of Family, Youth and Community Sciences, Institute of Food and Agricultural Sciences, University of Florida, Gainesville, FL 32611. 


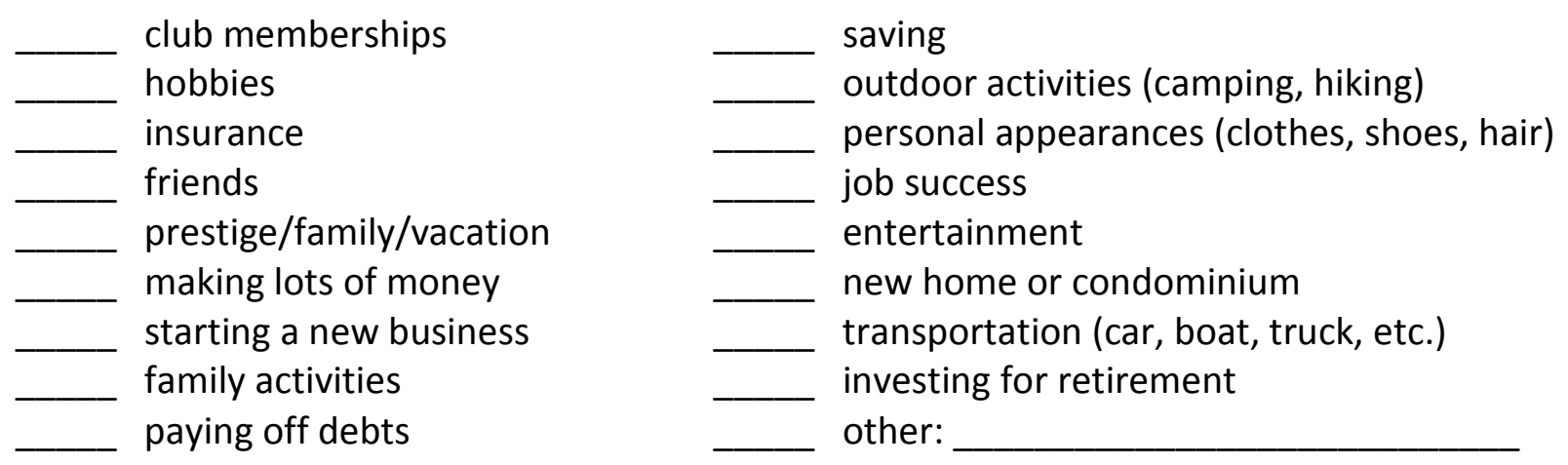

Now compare your list with your checkbook or spending receipts. Are you spending money on things that are really important to you and your family?

Do you and your family agree on your spending values and patterns? It's hard enough for one person to decide which item is most important. It's even harder when two or more people who share money have to decide where the money should go. That is why it is important for all family members to openly communicate about their spending priorities. Communication and joint decision-making are especially important when it comes to your family's budget, savings, and use of credit.

\section{FINANCIAL FORECASTING}

You need to look into the future and see where you want to be before you can get there. Create a list of your family's financial goals. It might look something like this:

- Home ownership

- Higher education for yourself and/or your children

- Cash reserve for emergencies (equal to three to six months of expenses) in case of unemployment, illness, or family emergency

- Decreased debt load

- Reserve money for special needs (house down payment, house remodeling, family vacations, braces for children's teeth)

- Adequate insurance against loss

- Retirement income

Financial goals should identify what you want to do with your money within a given period of time. Goals give you direction. They give you a purpose for the way you spend your money. Think about the things you want your money to do for you now and in the future. Think about your short-term, intermediate, and long-term goals.

Short-term goals are the things you want to get done in the next day, week, month, 6 months, or year. Intermediate goals are the things you want to accomplish in the next 1 to 5 years. Longterm goals are the things you want to accomplish in more than 5 years. All goals should be SMART: 
- Be $\underline{\text { Specific }}$

- Be Measurable

- Be Attainable

- Be Realistic

- Be Timely

What constitutes a goal? A statement such as "I want to save money" is too vague. It becomes a realistic financial goal by adding a dollar amount, and a timeframe. For instance, "I want to save \$25 a week for 12 months". An actual goal, however, would depend on an individual's or family's income and values. A Goal statement should answer What, When, and the How much?

Use Worksheet 1 to help you and your family decide what your financial goals are.

\section{InCOME AND SPENDING ANALYSIS (CASH FlOW)}

After you have listed your goals, you may question if it is possible to realize any of them and still pay day-to-day bills. To answer that question, you need to know your family's cash flow.

Your cash flow is the flow of money into your pocket and out again. How well do your income and expenses match? That sounds simple, but few of us take time to see what comes in and goes out each month. Use the "Cash Flow Worksheet" (Worksheet 2) to list your income and your expenses for one month. List all of your monthly income, include your salary, tips, child support, alimony, tax refund, dividends, interest from investment or savings accounts, capital gains from investment sales, and income for rental property or royalties.

Also keep a record of your expenses for the month. Use check stubs and receipts to monitor your spending. Include your fixed and flexible expenses. Fixed expenses are rent or mortgage payments, installment loans, insurance payments, and other regular payments. Flexible expenses are the budget items you have more control over. These include food, clothing, entertainment, utilities, etc.

When income exceeds expenses, you will have money to put in your savings program. If your income does not exceed expenses, see what you can do to increase your income or decrease your expenses. Look at your budget to see if you can eliminate some expenses. Perhaps you can reduce your flexible expenses? Be honest with yourself. Most expenses that are not fixed can be reduced, even if only a little bit.

\section{PLAN YOUR SPENDING}

The key to financial comfort and future financial success is budgeting. In this manner, you control your money instead of your money controlling you. With just a few months of disciplined spending, you can reverse overspending, free extra money for savings and investments, and build a cash cushion for emergencies. A budget is a boundary for your 
spending. When you allow $\$ 73$ a week for food, you have set a spending boundary. A complete budget can be used to determine spending guidelines.

\section{SPENDING GUIDELINES}

Spending guideline percentages may be useful when you examine your spending patterns. Spending guidelines are for comparison purposes only. They are not hard and fast rules. One family may choose to spend 40 percent on housing and less on clothing, credit, and transportation, while another may choose to spend more on transportation and less on housing. Here are some common spending guidelines:

Housing (utilities and supplies)

Food

Transportation (gas, oil, fares, passes)

Clothing

Medical (dental, prescriptions, health ins.)

Auto insurance
33-35\% Life insurance

18-25\% Credit obligation (auto payment)

$12-15 \%$

7-9\% Savings

6-12\% Recreation/entertainment

6-8\% Religious donations/charities

$2-10 \%$

Essential living expenses (shelter, food, clothing) and transportation, account for approximately three-fourths of take-home pay. A complete spending guideline will account for 100 percent of your income, regardless of how it is subdivided. You can compare your take-home pay to a pie. If you cut one slice too big, all the other pieces will have to be cut smaller or else you will have to borrow to make ends meet. The pie can only go so far.

\section{HOW TO MAKE A BUDGET}

Do you have a written plan that guides your spending? If not, use Worksheet 3 or the money management calendar to plan a monthly budget. List what you plan to spend as well as what you actually spent. Use check stubs and receipts to verify your spending. As you develop your plan, see if you have allowed enough money for the following items that pertain to you:

- Major expenses. Future goals such as adding rooms to your home, buying a car, paying for your child's education, gifts or furniture.

- Emergencies. Unavoidable costs such as medical expenses, auto accidents, unemployment, car repairs, house repair, and appliance repairs.

- Irregular or periodic expenses. Occurring annually or more often such as school supplies and clothes; house, car, health, life, and disability insurance; registration fees, uniforms and pictures for children in groups such as football, baseball, and basketball leagues; family vacations; birthday and holiday gifts; taxes and license plates.

- Debts. Such as past-due bills and credit card debts. 
- Monthly expenses. Basics such as savings or investment rent or mortgage, utilities, household supplies, food, contributions, installment payments, and medicine.

- Daily expenses. School lunch, snacks, transportation, and meals out.

- Miscellaneous expenses. Dues, subscriptions, laundry, clothing purchases and repairs, movies, recreation, and personal care.

\section{PLAN FOR SAVINGS}

When making your budget it is a good idea to plan for savings first. You can grow richer each month if you pay yourself a regular amount first. For instance, each month before you pay your bills, put 10 percent of your gross pay into your savings fund. If you do this at the beginning of the month, your entire paycheck will not slip through your fingers. But, if you wait until the end of the month, there may not be anything left to save. Paying yourself first gives you an automatic, systematic way to make your money grow. Regardless of your occupation or your income, this system works. This type of monthly deposit can also be accomplished through a payroll deduction. Check with your employer to see if such a plan is available where you work. If not, check with your bank to see if they will transfer the funds to your savings account monthly on the same designated date.

Another option to consider is putting a portion of a pay raise into a savings account. Also, you can empty your change into a can at the end of every day. Then at the end of the month, roll the coins and put them in your savings account. Consider saving your tax refund or other 'windfalls' that you experience. Lesson 5 offers more information on options for saving and investments.

\section{REVIEW YOUR SPENDING}

After establishing a plan for spending and saving, you need to carry it out. Keep track of your expenses to see that you are abiding by the plan. If not, or if you have unplanned expenditures, be prepared to make adjustments. If you spend more than you earn, you must either increase your income or decrease your expenditures.

\section{Summary of Suggested Activities to Start Your Financial Action Plan}

Schedule a family get-together. Have each person write down one specific spending goal. Then, select a family goal for this year. Discuss a plan for reaching each goal.

- Identify your total monthly income.

- Keep a record of all your spending for a month.

- Develop a spending plan for the year and stick to it. 


\section{Worksheet 1}

Briefly describe goals:

\begin{tabular}{|c|c|c|c|}
\hline Goal & Total Cost & $\begin{array}{l}\text { Cost per } \\
\text { Month }\end{array}$ & $\begin{array}{l}\text { Target date for goal } \\
\text { completion }\end{array}$ \\
\hline \multicolumn{4}{|c|}{ Short-term (within the next 12 months) } \\
\hline & & & \\
\hline & & & \\
\hline & & & \\
\hline & & & \\
\hline & & & \\
\hline & & & \\
\hline & & & \\
\hline Interr & & & \\
\hline & & & \\
\hline & & & \\
\hline & & & \\
\hline & & & \\
\hline & & & \\
\hline & & & \\
\hline & & & \\
\hline Long- & & & \\
\hline & & & \\
\hline & & & \\
\hline & & & \\
\hline & & & \\
\hline & & & \\
\hline & & & \\
\hline & & & \\
\hline
\end{tabular}

\section{Family Goals}


Worksheet 2

\begin{tabular}{l} 
Month Cash Flow W \\
Income \\
\hline Salary and tips \\
Interest, dividends, pensions \\
Child support \\
Other: \\
Total Monthly Income \\
\hline Expenses \\
Religious donations/charities \\
Other: \\
Rent or mortgage \\
Utilities (telephone, water, electricity, cable, internet, gas) \\
Food \\
Transportation \\
Clothing
\end{tabular}

Total Monthly Expenses

Amount \$

Amount \$

$\$$

Amount $\$$

Income less expenses 
Worksheet 3 (January-June)

\section{Yearly Plan and Spending Chart}

\begin{tabular}{|c|c|c|c|c|c|c|c|c|c|c|c|c|}
\hline & \multicolumn{2}{|c|}{ January } & \multicolumn{2}{|c|}{ February } & \multicolumn{2}{|c|}{ March } & \multicolumn{2}{|c|}{ April } & \multicolumn{2}{|c|}{ May } & \multicolumn{2}{|c|}{ June } \\
\hline Expenses & Plan & Spent & Plan & Spent & Plan & Spent & Plan & Spent & Plan & Spent & Plan & Spent \\
\hline Alimony/child sup & & & & & & & & & & & & \\
\hline Business expenses & & & & & & & & & & & & \\
\hline Child care & & & & & & & & & & & & \\
\hline Clothing & & & & & & & & & & & & \\
\hline - Laundry/dry clea & & & & & & & & & & & & \\
\hline Contributions & & & & & & & & & & & & \\
\hline $\begin{array}{l}\text { Education, self- } \\
\text { improvement }\end{array}$ & & & & & & & & & & & & \\
\hline Food \& groceries & & & & & & & & & & & & \\
\hline - Alcohol \& tobacc & & & & & & & & & & & & \\
\hline - Meals eaten out & & & & & & & & & & & & \\
\hline Gifts & & & & & & & & & & & & \\
\hline Hair care/cuts & & & & & & & & & & & & \\
\hline $\begin{array}{l}\text { Home furnishings, } \\
\text { equipment }\end{array}$ & & & & & & & & & & & & \\
\hline $\begin{array}{l}\text { Household } \\
\text { maintenance/help }\end{array}$ & & & & & & & & & & & & \\
\hline Insurance & & & & & & & & & & & & \\
\hline - Automobile & & & & & & & & & & & & \\
\hline - Disability & & & & & & & & & & & & \\
\hline - Home & & & & & & & & & & & & \\
\hline - Life & & & & & & & & & & & & \\
\hline - Medical & & & & & & & & & & & & \\
\hline - Property & & & & & & & & & & & & \\
\hline Medical - Dentist & & & & & & & & & & & & \\
\hline
\end{tabular}




\begin{tabular}{|c|c|c|c|c|c|c|c|c|c|c|c|c|}
\hline $\begin{array}{l}\text { Expenses (Jan-June) } \\
\text { continued }\end{array}$ & Plan & Spent & Plan & Spent & Plan & Spent & Plan & Spent & Plan & Spent & Plan & Spent \\
\hline - Physician & & & & & & & & & & & & \\
\hline - other & & & & & & & & & & & & \\
\hline Miscellaneous & & & & & & & & & & & & \\
\hline Monthly bills & & & & & & & & & & & & \\
\hline - Auto payment & & & & & & & & & & & & \\
\hline - Bank credit cards & & & & & & & & & & & & \\
\hline - Cable TV & & & & & & & & & & & & \\
\hline - Department stores & & & & & & & & & & & & \\
\hline - Loans & & & & & & & & & & & & \\
\hline - Rent or mortgage & & & & & & & & & & & & \\
\hline - Spa \& health club & & & & & & & & & & & & \\
\hline - Other & & & & & & & & & & & & \\
\hline Pets & & & & & & & & & & & & \\
\hline Recreation/entertainment & & & & & & & & & & & & \\
\hline Savings, investments & & & & & & & & & & & & \\
\hline Transportation: bus, taxi & & & & & & & & & & & & \\
\hline - Gas & & & & & & & & & & & & \\
\hline - Vehicle maintenance & & & & & & & & & & & & \\
\hline Utilities & & & & & & & & & & & & \\
\hline - Electricity & & & & & & & & & & & & \\
\hline - Garbage & & & & & & & & & & & & \\
\hline - Telephone & & & & & & & & & & & & \\
\hline - Water \& sewer & & & & & & & & & & & & \\
\hline - Other & & & & & & & & & & & & \\
\hline TOTAL EXPENSES & & & & & & & & & & & & \\
\hline Income less expenses & & & & & & & & & & & & \\
\hline
\end{tabular}


Worksheet 3 (July-December)

\section{Yearly Plan and Spending Chart}

\begin{tabular}{|c|c|c|c|c|c|c|c|c|c|c|c|c|}
\hline Month & \multicolumn{2}{|c|}{ July } & \multicolumn{2}{|c|}{ August } & \multicolumn{2}{|c|}{ September } & \multicolumn{2}{|c|}{ October } & \multicolumn{2}{|c|}{ November } & \multicolumn{2}{|c|}{ December } \\
\hline Expenses & Plan & Spent & Plan & Spent & Plan & Spent & Plan & Spent & Plan & Spent & Plan & Spent \\
\hline Alimony/child sup & & & & & & & & & & & & \\
\hline Business expenses & & & & & & & & & & & & \\
\hline Child care & & & & & & & & & & & & \\
\hline Clothing & & & & & & & & & & & & \\
\hline - Laundry/dry clea & & & & & & & & & & & & \\
\hline Contributions & & & & & & & & & & & & \\
\hline $\begin{array}{l}\text { Education, self- } \\
\text { improvement }\end{array}$ & & & & & & & & & & & & \\
\hline Food \& groceries & & & & & & & & & & & & \\
\hline - Alcohol \& tobacc & & & & & & & & & & & & \\
\hline - Meals eaten out & & & & & & & & & & & & \\
\hline Gifts & & & & & & & & & & & & \\
\hline Hair care/cuts & & & & & & & & & & & & \\
\hline $\begin{array}{l}\text { Home furnishings, } \\
\text { equipment }\end{array}$ & & & & & & & & & & & & \\
\hline $\begin{array}{l}\text { Household } \\
\text { maintenance/help }\end{array}$ & & & & & & & & & & & & \\
\hline Insurance & & & & & & & & & & & & \\
\hline - Automobile & & & & & & & & & & & & \\
\hline - Disability & & & & & & & & & & & & \\
\hline - Home & & & & & & & & & & & & \\
\hline - Life & & & & & & & & & & & & \\
\hline - Medical & & & & & & & & & & & & \\
\hline - Property & & & & & & & & & & & & \\
\hline Medical - Dentist & & & & & & & & & & & & \\
\hline
\end{tabular}




\begin{tabular}{|c|c|c|c|c|c|c|c|c|c|c|c|c|}
\hline $\begin{array}{l}\text { Expenses (July-Dec) } \\
\text { continued }\end{array}$ & Plan & Spent & Plan & Spent & Plan & Spent & Plan & Spent & Plan & Spent & Plan & Spent \\
\hline - Physician & & & & & & & & & & & & \\
\hline - other & & & & & & & & & & & & \\
\hline Miscellaneous & & & & & & & & & & & & \\
\hline Monthly bills & & & & & & & & & & & & \\
\hline - Auto payment & & & & & & & & & & & & \\
\hline - Bank credit cards & & & & & & & & & & & & \\
\hline - Cable TV & & & & & & & & & & & & \\
\hline - Department stores & & & & & & & & & & & & \\
\hline - Loans & & & & & & & & & & & & \\
\hline - Rent or mortgage & & & & & & & & & & & & \\
\hline - Spa \& health club & & & & & & & & & & & & \\
\hline - Other & & & & & & & & & & & & \\
\hline Pets & & & & & & & & & & & & \\
\hline Recreation/entertainment & & & & & & & & & & & & \\
\hline Savings, investments & & & & & & & & & & & & \\
\hline Transportation: bus, taxi & & & & & & & & & & & & \\
\hline - Gas & & & & & & & & & & & & \\
\hline - Vehicle maintenance & & & & & & & & & & & & \\
\hline Utilities & & & & & & & & & & & & \\
\hline - Electricity & & & & & & & & & & & & \\
\hline - Garbage & & & & & & & & & & & & \\
\hline - Telephone & & & & & & & & & & & & \\
\hline - Water \& sewer & & & & & & & & & & & & \\
\hline - Other & & & & & & & & & & & & \\
\hline TOTAL EXPENSES & & & & & & & & & & & & \\
\hline Income less expenses & & & & & & & & & & & & \\
\hline
\end{tabular}

